\title{
Statskirkens Fortyskning i Nordslesvig.
}

„Naar jeg forstaar Anvisningen af 18. Decbr. 1888 rigtigt", sagde Provst Schmidt fra Svenstrup 1891 paa Provinssynoden i Rendsborg, „saa skal den ........ muliggjøre Indførelsen af det tyske Sprog ved Gudstjenesten indenfor en overskuelig Fremtid, ....... og det er kun i sin Orden, at det tyske Sprog fremtidig bliver Kirkesproget i Nordslesvig."

Denne Ytring vakte megen Opmærksomhed, thi Provs Schmidt er ikke blot en alvorlig og besindig Mand, men han er tillige fra Barnsben af kjendt med Forholdene i Nordslesvig, og han traadte paa samme Synode i Skranken for de Krav, som de meget omtalte „77 nordslesvigske Præster" har rejst. Det føltes nærmest som en pinlig Overraskelse, da han omtalte Statskirkens Fortyskning indenfor en overskuelig Fremtid som en ganske naturlig og selvfølgelig Sag, der var hævet højt over alle tysksindede Præsters afvigende Meninger. Provsten har imidlertid haft god Grund til at udtale sig, som han gjorde. I Virkeligheden er Statskirkens Fortyskning ikke en fjernt lurende Fare, som mange endnu er tilbøjelige til at tro; den er trærtimod et vel planlagt, snildt og energisk fremmet Arbejde, som vore verdslige 
og kirkelige Myndigheder endrægtigt søgerat tilendebringe hurtigst muligt.

Allerede for syv Aar siden paaviste jeg her i Aarbøgerne ${ }^{*}$ ) Statskirkens tiltagende Fortyskning. Af den da meddelte statistiske Oversigt fremgik det, at der siden den sidste Krigs Udbrud var rettet to stærke Stormløb imod den danske Gudstjeneste i vore Kirker. Under det første Stormløb, som var endt inden Freden sluttedes, fortrængtes det danske Sprog fuldstændigt af 41 slesvigske Kirker. Ved Nytaarstid 1864 blev der nemlig afholdt dansk Gudstjeneste i 162 efter Krigen derimod i kun 121 slesvigske Kirker.

Det næste Stormløb begyndte med nogle smaa Tilløb sidst i Halvfjerserne, men tog først Fart ti Aar senere, efter at Skolesproget var bleven tysk, og Regeringen i Generalsuperintendent $\mathrm{K}$ aftan havde fundet en Mand, der var villigere til at gaa dens Erinde og: fremme dens Planer, end den gamle, bondefødte Generalsuperintendent Godt, som aldrig glemte sit danske Modersmaal. Allerede i Oktober 1890, da den i Aarbøgerne meddelte Statistik optoges, var den danske Gudstjeneste endvidere bleven afskaffet i 3 Sogne og der var indført delvis tysk Gudstjeneste i 39 Sogne, hvor Kirkesproget før havde været udelukkende dansk. Ialt blev der endnu i 1890 afholdt dansk Gudstjeneste i 118 Sogne, hvoraf dog kun 69 Sogne havde udelukkende dansk Gudstjeneste.

Der er nu gaaet 7 Aar, siden denne Statistik blev optagen. I den Tid har vi af og til kunnet læse $i$ vore Aviser om 'Indførelse af tysk Gudstjeneste i Nordslesvig,

*) Sønderjydske Aarbgger 1890 Side 274 „Tysk Gudstjeneste i Nordslesvig". 
men der har altid været Tale om et enkelt Sogn ad Gangen, og der har ligget Maaneder imellem de enkelte Tilfælde. Dertil kommer endnu, at Pressen ikke har bragt alle Tilfælde af den Art til Offentlighedens Kundskab. Under disse Forhold tabes Overblikket let. Man iagttager kun Enkeltheder og bliver tilbøjelig til at undervurdere Helhedens Betydning. Det er imidlertid vigtict for os at være velunderrettede om Fortyskningens Fremskridt, ogsaa paa dette Omraade, for at vi kan tage vore Forholdsregler derimod. En samlet Fremstilling af Statskirkens Fortyskning siden 1864 er derfor atter paa sin Plads og vli blive given paa Grundlag af en nylig optagen Statistik.

\section{I.}

Paa hosstaaende Tavler giver jeg først en Oversigt over det tyske Sprogs Stilling i vore Kirker Sommeren 1897 :

\section{Haderslev Provsti.}

\begin{tabular}{|c|c|c|}
\hline Sogn. & |Tysk Gudstjeneste afholdes. & Bemærkninger. \\
\hline Haderslev & $\begin{array}{l}\text { hver Søn- og Helligdag } \\
\text { som Højmesse. }\end{array}$ & $\begin{array}{l}\text { [)er afholdes hver Son- og } \\
\text { Helligdag far eller senere } \\
\text { dansk Gudstjeneste. }\end{array}$ \\
\hline Skodborg & $\begin{array}{l}12 \text { Gange aarlig, den første } \\
\text { Søndag i hver Maaned om } \\
\text { Eftermiddagen. }\end{array}$ & \\
\hline $\begin{array}{c}\text { Gl. } \\
\text { Haderslev }\end{array}$ & $\begin{array}{l}15 \text { Gange aariig, den forste } \\
\text { Søndag i hrer Maaned og } \\
\text { anden Jule- Paaske- og } \\
\text { Pintsedag. Hojmesse. }\end{array}$ & $\begin{array}{l}\text { Paa disse Dage bortfalder } \\
\text { den danske Gudstjeneste. }\end{array}$ \\
\hline Sommersted & $\begin{array}{c}12 \text { Gange aarlig, den forste } \\
\text { Søndag i hver Maaned on } \\
\text { Eftermiddagen. }\end{array}$ & \\
\hline Halk & $\begin{array}{c}2 \text { Gange aarlig, anden Jule- } \\
\text { og Paaskedag } \\
\text { om Fftermiddagen. }\end{array}$ & $\begin{array}{l}\text { Allerede tidligere blev der } \\
\text { afholdt tysk Altergang1-2 } \\
\text { Gange aarlig i Sognet. }\end{array}$ \\
\hline Ok & $\begin{array}{l}2 \text { Gange aarlig, Foraar og } \\
\text { Tffteraar, Søndag Formidd. }\end{array}$ & $\begin{array}{l}\text { Den danske Gudstjeneste } \\
\text { bortfalder disse Dage. }\end{array}$ \\
\hline
\end{tabular}




\begin{tabular}{|c|c|c|}
\hline Sogn. & | Tysk Gudstjeneste afholdes. & Bemærkninger. \\
\hline Frørup & $\begin{array}{c}9 \text { Gange aarlig um Efter- } \\
\text { middagen. }\end{array}$ & $\begin{array}{l}\text { Allerede tidligere blev dex } \\
\text { afholdt tysk Alteryang } 1-2 \\
\text { aarlig i Sownet. }\end{array}$ \\
\hline Stepping & $\begin{array}{c}6 \text { Gange aarlig om Efter- } \\
\text { middageu. }\end{array}$ & $\begin{array}{l}\text { Allerede tidliurere blev der } \\
\text { afbuldt tysk Altergang1-2 } \\
\text { Gange aarlig i Sugnet. }\end{array}$ \\
\hline Hjerndrup & $\begin{array}{c}4 \text { Gange aarlig om Efter- } \\
\text { middagren. }\end{array}$ & \\
\hline Jels & $\begin{array}{l}\text { 6 Gange aarlig, } 3 \text { Sondage, } \\
\text { 2. Jule-Paaske-o. I'intsedag. }\end{array}$ & $\begin{array}{l}\text { Den danske Gudstjeneste } \\
\text { bortfalder paa disse Thage. }\end{array}$ \\
\hline Vilstuup & $\begin{array}{l}15 \text { Gange aarlig; den forste } \\
\text { Sondag i hver Maaned, } \\
\text { 2. Jule-, Paaske-o. Pintse dag } \\
\text { om Formiddauren*) }\end{array}$ & $\begin{array}{l}\text { Den danske ('udstjeneste } \\
\text { afholdes on Ffter- } \\
\text { middagen paa disse I)age. }\end{array}$ \\
\hline Hanımelev & $\begin{array}{l}2 \text { Gange aarligr tysk Alter- } \\
\text { gangr. }\end{array}$ & 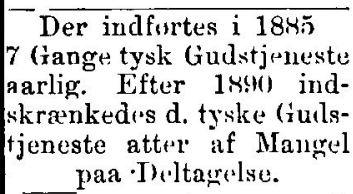 \\
\hline Jiegerup & $\begin{array}{c}12 \text { Gange aarligr linn forste } \\
\text { Sondag i hver Mataned. }\end{array}$ & 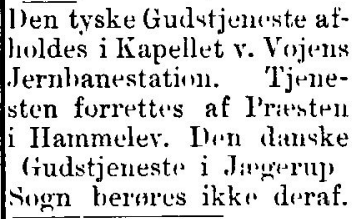 \\
\hline Aller & $\begin{array}{c}2 \text { Gainge aurligr tysk Alter- } \\
\text { gang. }\end{array}$ & \\
\hline Bjerning & $\begin{array}{c}1 \text { Gang aculig tysk Alter- } \\
\text { gang. }\end{array}$ & \\
\hline Tedsted & $\begin{array}{l}\text { 12 Gange aarlig: den forste } \\
\text { Sondag i liver Maned. }\end{array}$ & \\
\hline
\end{tabular}

l'rovstiet omfatter ialt 26 surne. Der afholdes ikke tysk Gudstjeneste i Sognene: Grarup, Starup, Moltup, Maugstrup, Vonsbæk, Aastrup, Fjelstrup, Hoptrup, Osby og Tyrstrup.

*) Hvor Cdtrykket „om Formiddagen“ bruges udun sirlige Bemierkninger betyder det Hovedgndstjenesten. 


\section{Tørninglen Provsti.}

\begin{tabular}{|c|c|c|}
\hline Sogn. & Tysk Gudstjeneste afholdes. & Bemærkninger. \\
\hline Toftlund & $\begin{array}{l}15 \text { Gange aarlig; den forste } \\
\text { Søndag i hver Maaned og } \\
\text { anden Jule-, l'aaske og } \\
\text { Pintsedar om Formiddagen. }\end{array}$ & $\begin{array}{l}\text { Der afholdes p. disse Dage } \\
\text { dansk Gudstjeneste om } \\
\text { Eftormiddaren. }\end{array}$ \\
\hline Rodlding & $\begin{array}{l}12 \text { Gange aarlig; } 9 \text { Simdage } \\
\text { or anden Jule-, Iaaske- org } \\
\text { Pintsedag. } 6 \text { Gange orn } \\
\text { Formiddaren or } 6 \text { (range } \\
\text { om Eftermiddacren. }\end{array}$ & $\begin{array}{l}\text { I)en danske Gudstjeneste } \\
\text { bortfalder } 3 \text { Gange aarlig } \\
\text { i SkraveKirke og } 3 \text { (tange } \\
\text { i Rodding Kirke af Hen- } \\
\text { syn til den tyske Guds- } \\
\text { tjeneste. }\end{array}$ \\
\hline Skjælbæk & $\begin{array}{l}\text { 15 Gange aarlig; den fırste } \\
\text { Sonclag i liver Maaned og } \\
\text { anden Jule-, Iaaske- orn } \\
\text { Pintsedag um Formiduagen. }\end{array}$ & 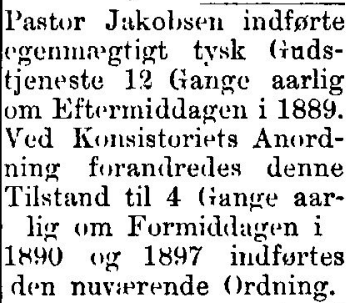 \\
\hline Hvidaling & $\begin{array}{l}17 \text { (iange aarlig; don furste } \\
\text { Sundag i hver Maaned, an- } \\
\text { den Jule-, Paaske-o. Pintse- } \\
\text { dag, Bededag og Kejserens } \\
\text { Fordselsdag. }\end{array}$ & $\begin{array}{l}\text { Den tyske liudstjenteste af- } \\
\text { holdo's i Skolen ved Hvid- } \\
\text { ding Jernloanestation og } \\
\text { yjor derfor intet Skaar i } \\
\text { den danske Gudstjeneste. }\end{array}$ \\
\hline Nustrup & $\begin{array}{c}\text { 2-3 Gange aarlig tysk } \\
\text { Altergang. }\end{array}$ & $\begin{array}{l}\text { Der har ograa voret ind- } \\
\text { furt tysk l'rirdiken, men } \\
\text { lon er atter bortfalden af } \\
\text { Mangel paa Deltagelse. }\end{array}$ \\
\hline Roager & $\begin{array}{l}4 \text { Gange udenfor den sud- } \\
\text { vanlige Swndausguds- } \\
\text { tjeneste. }\end{array}$ & $\begin{array}{l}\text { Der findes et Par Told- } \\
\text { embedsiniend i Sngnet. }\end{array}$ \\
\hline Høјгup & $\begin{array}{c}12 \text { Gange aarlig om Efter- } \\
\text { middagen. }\end{array}$ & $\begin{array}{l}\text { Den tidligere Sogneprest } \\
\text { hegyndto i Firsern at af- } \\
\text { holde tysk (iudstjeneste i } \\
\text { Arnum skole. Den nu- } \\
\text { værende Sognepraest af- } \\
\text { holder egenmaegtig tysk } \\
\text { Gudstjeneste i Kirken. }\end{array}$ \\
\hline
\end{tabular}

Provstiet omfatter 24 Sogne. Der afholdes ikke tysk Gudstjeneste i Sognene: Agerskov, Arrild, Beftoft, Tirslund, Branderup, Brøns, Fol, Gram, Hygum, Lintrup, Hjerting, Østerlindet, Rejsby, Skrave, Skrydstrup, Spandet og Vodder. 


\section{Aabenraa Provsti.}

\begin{tabular}{|c|c|c|}
\hline Sogn. & Tysk Gudstjeneste afholdes. & Bemærkninger. \\
\hline Aabenraa & $\begin{array}{c}\text { hver Søn- og Helligdag som } \\
\mathrm{H}_{y j \text { jmesse. }}\end{array}$ & $\begin{array}{l}\text { Ter afholdes hver Son- og } \\
\text { Helligdag f } ₫ \text { r eller senere } \\
\text { dansk Gudstjeneste. }\end{array}$ \\
\hline Adsbøl & $\begin{array}{l}\text { Graasten Slotskajel hver } \\
\text { anden Sin- og Helligrlag. }\end{array}$ & $\begin{array}{l}\text { I AdsbolKirkt: afholdes der } \\
\text { kun dansk Gudstjeneste. }\end{array}$ \\
\hline Kliplev & $\begin{array}{c}5 \text { Gange aarligr; } 2 \text { Søndage } \\
\text { og anden Jule-, Paaske- og } \\
\text { Pintsedag. }\end{array}$ & \\
\hline Riis & $\begin{array}{c}12 \text { Gange aarlig; } 9 \text { Sundage } \\
\text { og anden Jule-, Paaske- og } \\
\text { P'intsedag. }\end{array}$ & $\begin{array}{l}\text { 5 Sondace aarlig afhol- } \\
\text { des dir ikke dansk Guds- } \\
\text { tjeneste af Hensyn til den } \\
\text { tyske. }\end{array}$ \\
\hline Uge & $\begin{array}{l}15 \text { Gange aarlig; den furste } \\
\text { Ssndag i liver Maaned og } \\
\text { anden Jule-, Paaske- og } \\
\text { Pintsedag. }\end{array}$ & $\begin{array}{l}\text { Indfurt } 1888 \text { fter Anscig- } \\
\text { ning af den lokjendte Pa- } \\
\text { stor Pries z under Fore- } \\
\text { rivende af, at det var nod- } \\
\text { vendi for for Arhejulerne } \\
\text { v. den dervarende Nergel- } \\
\text { lane. }\end{array}$ \\
\hline Ringenæs & $\begin{array}{l}15 \text { Gange aarlig; den forste } \\
\text { Søndag i hver Maaned, } 2 . \\
\text { Jule-, Paaske- o. Pintsedag. }\end{array}$ & $\begin{array}{l}\text { Der afholdes paa disse } \\
\text { Dage dansk (4udintjeneste } \\
\text { om Lftermidilaron. }\end{array}$ \\
\hline Kvæl's & $\begin{array}{l}5 \text { Gange aarlig; } 2 \text { Sondase } \\
\text { lioraar orkfteraar og anden } \\
\text { Jule-, Paaske- og Pintsedag. }\end{array}$ & $\begin{array}{l}\text { Indfurt af Hensyn til tyske } \\
\text { T'jenestefolk yaa et Par } \\
\text { Herregaarde i Sognet. }\end{array}$ \\
\hline Bjolderup & $\begin{array}{l}4 \text { Gange aarlig; en Sondag } \\
\text { i Efteraaret og anden Jule-, } \\
\text { Paaske- og Pintsedag om } \\
\text { Formiddagen. }\end{array}$ & $\begin{array}{l}\text { Der afholdes yad disse } \\
\text { Dage dansk Gudstjeneste } \\
\text { urn Eftermidagen. }\end{array}$ \\
\hline Hjortkjær & $\begin{array}{l}5 \text { Gange aar ligr } 2 \text { Sandage } \\
\text { (forbunden med Altergang) } \\
\text { ig anden Jule-, Paaske- og } \\
\text { Pintsedag o.Fftermidrlagen. }\end{array}$ & \\
\hline Holeb $\varnothing l$ & $\begin{array}{l}\text { 15 Gange aarlig; den forste } \\
\text { Sondag i hver Maaned og } \\
\text { anden Jule-, Paaske- og } \\
\text { Pintsedag o.Eftermiddagen. }\end{array}$ & $\begin{array}{l}\text { Indfort 1843, mens Sognet } \\
\text { var uden Prast. Allerede } \\
\text { tidligere blev der dog af- } \\
\text { holdt tysk Gudstjeneste } \\
6 \text { Gange aarlig. }\end{array}$ \\
\hline Bedsted & $\begin{array}{l}6 \text { Gange aarlig om Formid- } \\
\text { dagen. }\end{array}$ & $\begin{array}{l}\text { Anordnet af } K \text { onsistoriet } \\
\text { af Hensyn til en af den } \\
\text { tyske Forening i Viprk sat } \\
\text { Petition. }\end{array}$ \\
\hline Hellevad & $\begin{array}{c}2 \text { Gange aarlig om For } \\
\text { dacren. }\end{array}$ & $\begin{array}{l}\text { Anordnet af Kunsisturiet } \\
\text { af Hensyn til on af den } \\
\text { tyske Furening i Vark sat } \\
\text { Petitiun. }\end{array}$ \\
\hline
\end{tabular}




\begin{tabular}{l|c|c}
\hline \multicolumn{1}{c|}{ Sogn. } & Tysk Gudstjeneste afholdes. & Bemærkninger. \\
\hline Felsted & $\begin{array}{c}\text { 4 Gange aarlig om Efter- } \\
\text { middayen. }\end{array}$ & \\
\hline Varnæs & $\begin{array}{c}\text { Gange aarlig; ikke } \\
\text { officielt fastsat. }\end{array}$ & \\
\hline Ø.-Løgum & $\begin{array}{c}1-2 \text { Gange aarlig tysk } \\
\text { Altergang ; ikke ofticielt } \\
\text { fastsat. }\end{array}$
\end{tabular}

Provstiet omfatter 18 Sogne. Der afholdes ikke tysk Gudstjeneste i Sognene: Egvad, Løjt og Ensted.

\section{Sonderborg Provsti.}

\begin{tabular}{|c|c|c|}
\hline Sogn. & Tysk Gudstjeneste afholdes. | & Bemærkninger. \\
\hline Sønderborg & $\begin{array}{c}\text { hrver Swn- ogr Helligdag som } \\
\text { Hojjmesse. }\end{array}$ & $\begin{array}{l}\text { Der afholites her Swn- og } \\
\text { Helligilag f fir eller senere } \\
\text { dansk (tudstjeneste. }\end{array}$ \\
\hline $\begin{array}{l}\text { Avgusten- } \\
\text { borg }\end{array}$ & $\begin{array}{l}\text { hiver Syn- og Helligdag hele } \\
\text { Aaret. }\end{array}$ & $\begin{array}{l}\text { Der afholdes kun dansk } \\
\text { Gudstjeneste } 4 \text { Sondage } \\
\text { aarlig on Eftermiddagen. }\end{array}$ \\
\hline Nordborg & $\begin{array}{c}15 \text { Gange aarlig; den furste } \\
\text { Sindag i hrer Haaned og } \\
\text { anden Jule-, Paaske og } \\
\text { Pintsedag om Formiddagren } \\
\text { efter endt dansk Guds- } \\
\text { tjeneste. }\end{array}$ & $\begin{array}{l}\text { Den danske Gudstjeneste } \\
\text { afhwdes praa diss Dage } \\
\text { 1/a Time tidligrtre end sæd- } \\
\text { vanlig. }\end{array}$ \\
\hline Broager & $\mid \begin{array}{l}1 \text { o Gange aarlig; den sidste } \\
\text { Sondag i hver Haaned ogr } \\
\text { anden Jule-, Paaske- og } \\
\text { I'intsedag on Furmiddagell. }\end{array}$ & $\begin{array}{l}\text { Der afluhles paa disse } \\
\text { Dage dansk (indstjeneste } \\
\text { fur eller sinere. } \\
\text { Der afhohles paa disse }\end{array}$ \\
\hline Cllerup & 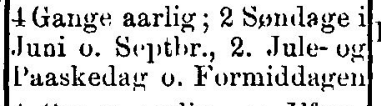 & $\begin{array}{l}\text { Der afholdes paa disse } \\
\text { rharg, clansk Gudstjeneste } \\
\text { for Hller senere. }\end{array}$ \\
\hline Ulkebøl & $\begin{array}{c}\text { 4 Gange aarlig om Efter- } \\
\text { niddlagren. }\end{array}$ & \\
\hline Ketting & $\begin{array}{c}4 \text { Gange aarlig oin Fifter- } \\
\text { middagen. }\end{array}$ & \\
\hline ysabild & $\begin{array}{c}\text { t Gauge anrliy om } \\
\text { middagen. }\end{array}$ & \\
\hline
\end{tabular}

Provstiet onfatter 20 Sogne. Der afholdes ik ke tysk Gudstjeneste j Sognene: Dybbol, Nybsl, Sottrup, Kejnes, Hyrup, Tandslet, Adserballe, Notmark, Egen, Svenstrup, Hagenbjerg og Okshol. 


\section{Tonder Norre-Provsti.}

\begin{tabular}{|c|c|c|}
\hline Sogn. & Tysk Gudstjeneste afholdes. & Bemærkninger. \\
\hline 'Tonter' & hver shon- ug IItlligdar. & 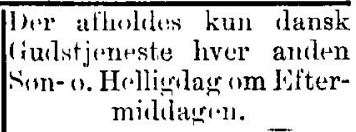 \\
\hline II!jer & 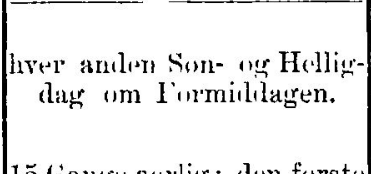 & 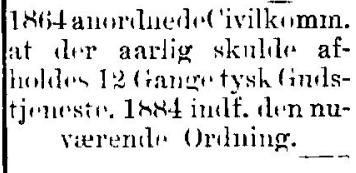 \\
\hline $\begin{array}{l}\text { Lowiun- } \\
\text { klosten: }\end{array}$ & 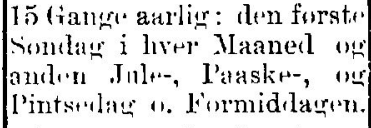 & \\
\hline Burkal & 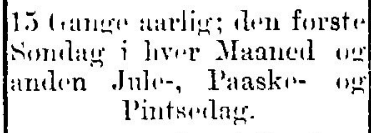 & 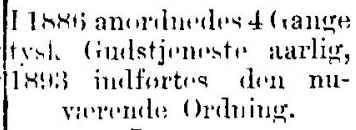 \\
\hline Tingler & 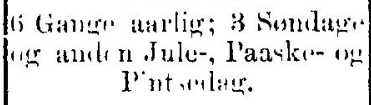 & \\
\hline Hosllul & 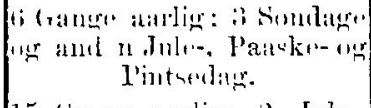 & - \\
\hline Bivele & 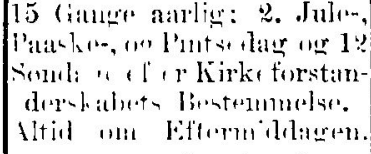 & 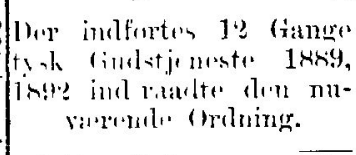 \\
\hline Alild & 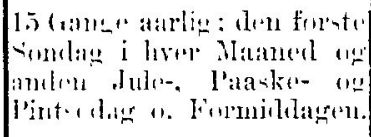 & 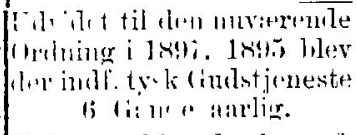 \\
\hline lighloride & 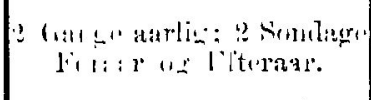 & 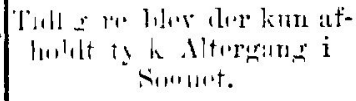 \\
\hline Ravited & 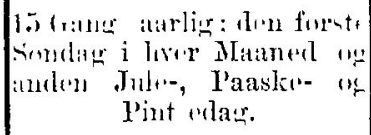 & 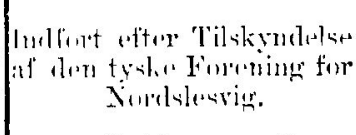 \\
\hline Hujst & 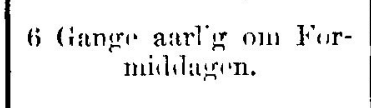 & 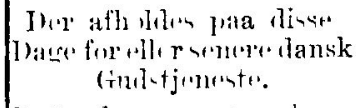 \\
\hline N.-I. & 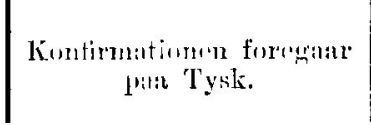 & 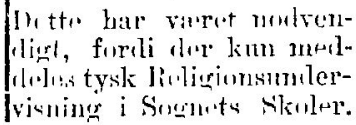 \\
\hline
\end{tabular}




\begin{tabular}{c|c|c}
\hline Sogn. & Tysk Gudstjeneste afholdes. & Bemærkninger. \\
\hline Udbjerg & hver Ssn- og Helligdag. & $\begin{array}{l}\text { Der aflioldes dansk Guds- } \\
\text { tjeneste 15 Gange aarlior: } \\
\text { den furste Ssmdag i hrer } \\
\text { Maaned og 2.Jule-,Paaske- } \\
\text { og Pintsedag om Efter- } \\
\text { middagen. }\end{array}$
\end{tabular}

Provstict omfatter 30 Sogne. Deraf har Sognene Rodenæs, Avntoft, Vesterland, Morsum, Nykirke og Kejtum kun ty sk Gudstjeneste og Sognene Ballum, Daler, Døstrup, Emmerlev, Medolden, Mogeltonder, Hjerpsted, Skads, Randerul, Romı og Visby kun dansk Gudstieneste.

\section{Tonder Sønder-Provsti.}

\begin{tabular}{|c|c|c|}
\hline Sogn & |Dansk Gudstjeneste afholdes.| & Bemærkninger. \\
\hline Braderup & $\left|\begin{array}{c}\text { DamskGudstjeneste12Gangere } \\
\text { aarlig }\end{array}\right|$ & \\
\hline Mertelby & $\mid \begin{array}{c}\text { 1)ausk Gudstjeneste } 4 \text { (tange } \\
\text { aarlig. }\end{array}$ & \\
\hline
\end{tabular}

\section{Flensborg Provsti.}

\begin{tabular}{|c|c|c|}
\hline Sogn. & |Dansk Gudstjen rste afholdes.| & Bemærkninger. \\
\hline Flenshorg & 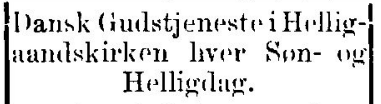 & \\
\hline Bov & 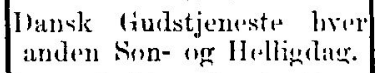 & \\
\hline Hanved & 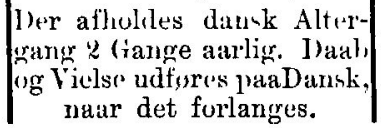 & \\
\hline
\end{tabular}

Tavlerne udviser, at der ialt afholdes dansk Gudstjeneste i 117 slesvigske Sogne. I 10 af disse Sogne, 
Haderslev, Aabenraa, Sonderborg, Tonder og Frue Sogn i Flenshorg, endvidere i de før til de "blandede Distrikter“ hørende Sogne Bov, Udbjerg, Brad erup, og Medelby samt i Avgustenborg har det danske Sjrog en underordnet Plads; i H anved afholdes der dansk Altergang; i Højer er begge Sprog sideordnede Tilbage bliver 105 Sogne paa Egne, hvor Folkesproget er rent dansk. Af dem har for Tiden 16 Sogne tysk Gudstjeneste mindst 15 Gange aarlig, 0: paa en Fjerdedel af Aarets Son og Helligdage; 29 Sogne har fra 2-12 Gange tysk Gudstjeneste aarlig, mens 6 Sogne kun har tysk Altergang og ét kun tysk Konfirmation. Tilbage bliver derefter ialt 53 Sogne, som.endnu ikke har tysk Gudstjeneste. Med andre Ord: I over Halvdelen af de 117 slesvirsske Sogne, der endnu har dansk Gudstjeneste, er Kirkespronet blandet; da Germaniseringsarbejdet begyndte i 1864, rar hirkesproget kun blandet i 11 af disse Sogne.

\section{II.}

De nu folgendle Tavler giver en kronologisk Oversigt over Statskirkens Fortyskning fra $1864-1897$.

1864.

Civilkommissærerne anordnede:

1) at den dankke Gudstjeneste skulde ophore i 41 mellemslesvigske Sogne, hvor der var bleven prædiket skiftevis paa Dansk og Tysk incltil Krigen;

2) at den danske Gudstjeneste i Sognene Udbjerg, Sonderløum, Humptrup Braderup, Kar lum, Ladelund, og Medelby skulde indskræukes til én Sondag Eftermildaig og éll Sondag Formiddag i liver Mataned; 
1864 3) at der skulde afholdes tysk Hoverlgudstjeneste oü kun dansk Eftemidiagsoudstjeneste i Byerne Haderslev, Aabenraa, sonderborrog $\mathrm{T}$ onder, or at don dauske Gudstjeneste i Augustenborg skilde indskimenles til 4 Sindage arrlig;

4) at her skulde afholdos tysk Gudstjeneste hver anden Som- or Helligh i Grasten (Slotskapellet) og 15 (jange arlig i Logumkloster, lid ciange andigr i Hojer, tiange andig i Nordbor" og ,nogle" Gange atrip i Broager Sogn.

Lfter Konsistoriets Anordning indfortes der tysk (xudstjeneste:

1876

1878

1879

1880

1882

1883

1884

1885

$1886^{\circ}$

1887

1888

1889

12 ciange andio i Skodborg.

5 ciange anrlig i liliples.

5 (iange atrlig i Riis.

(; Ciange aarlig i Holthol.

4 liallete atalig i Ringenas.

a) $1: 2$ (ialnge atalig 1 Riis.

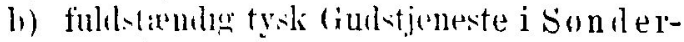
L. 1)

hror anden Son- or Hulliwdig i II ojer.

i Gampe atarlig i Hammolev.

4 liange atalig i liurkal.

15 Galuge andig i di]. IJallerslev.

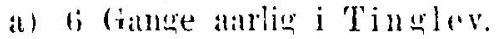

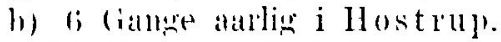

c) 1: cimpe atrlin i Sommorster.

(d) 12 ciange aitrlig i Toftlund.

e) 15 (iallge atallin i Curo.

a) 4 (bange arrlig i Kvars.

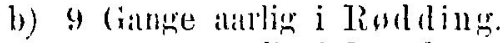

(c) 12 Gante alarlin i libede.

d) 12 (range atrlig i bians.

e) 15 (tiange atarlig i Hvidding.

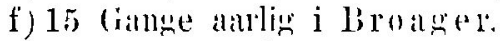

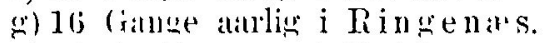

1890)

a) tysk Alteloana i Byldernp.

b) 2 Gange atrlig i Oksenvad.

c) 2 Gange atulig i Hiortkjær. 


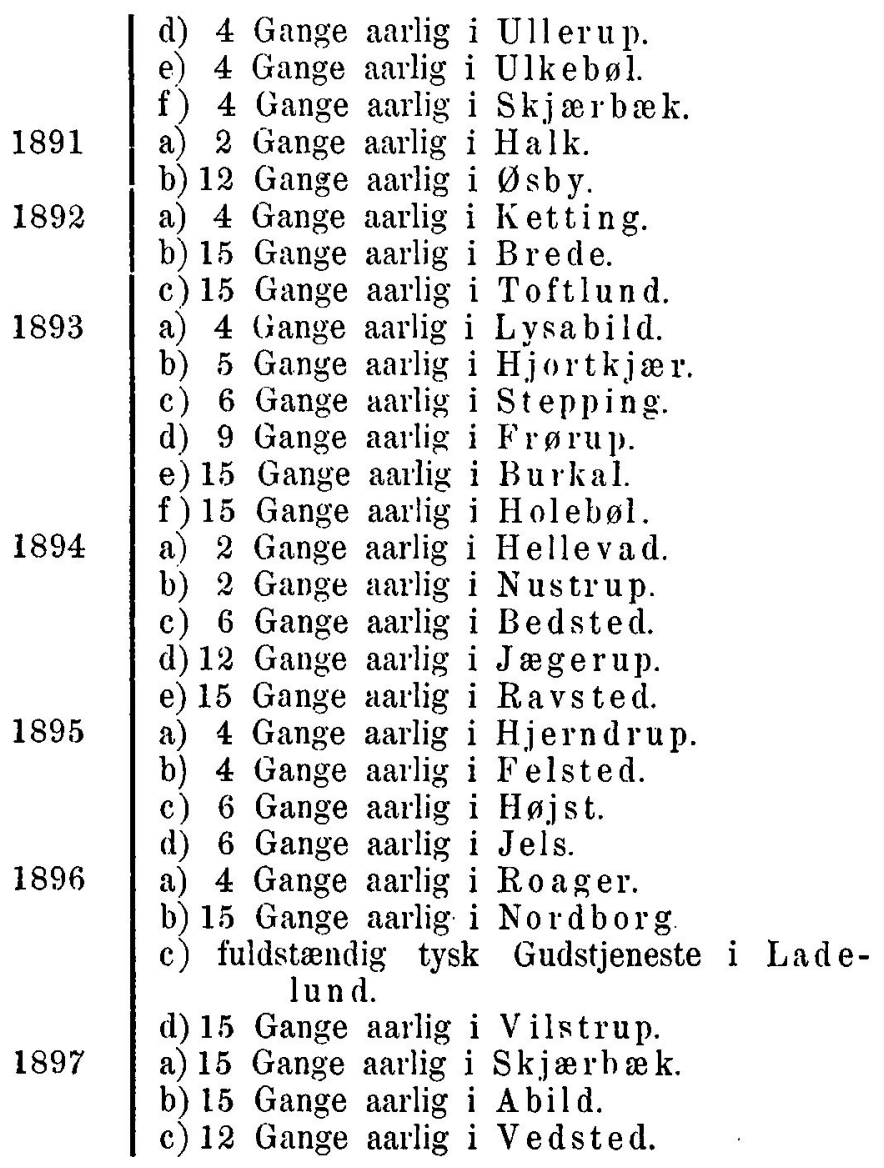

Til ovenstaaende Tavle bemærkes: Jeg savner Oplysninger angaaende det tyske Kirkesprogs gradvise Fremtrængen i de sidste Sogne af de tidligere „blandede Distrikter". Og der er ikke taget Hensyn til Indførelsen af tysk Gudstjeneste, hvor den som f. E. i Højrup er en Tilsnigelse af Sognepræsten og ikke officielt anordnet af Konsistoriet. 
Enkelte af de paa Tavlen opførte Aarstal gjor ikke Krav paa at være absolut nøjagtige, ilet nogle af mine Hjemmelsmænd har taget et vist Forbehold ved $i$ Skemaerne at tilf 6 je et "omtrent" eller lignende. Dette gjæalder log kun faa Tal ialt, ng Unøjagtigheden vil næppe viere ret stor $\mathrm{i}$ disse Tilfælde.

$I$ de paa Tavlen opforte Sogne Hammelev, Brøns, $\emptyset$ sby og Nustrup er den tyske Gudstjeneste atter ophørt eller af Mangel paa Deltagelse bleven indskranket til tysk Altergang et Par Gange om Aaret.

Iøvigt giver Tavlen i flere Henseender et godt Billede af Konsistoriets travle Fortyskningsarbejde. Man ser, hvorledes Strømmen vokser, alt som Tiden gaar. Aar for Aar tiltager den i Omfang og Styrke. Angrebene rettes ikke blot paa flere og tlere Sogne med ublandet Kirkesprog, men de fortsrettes systematisk overalt, hvor lidt tilfort Tyskhed muliggiør tysk Kirkebesgg.

\section{III.}

Anvisningen af 18. Dcbr. 1888 har allerede øvet en meget stor Indflydelse paa Statskirkens Fortyskning. Fra 1865-88 kan Fortyskuingen kun opvise smaa Fremskridt; fra 1888-90 har den derimod Vind $i$ alle Sejl. Derefter synes det starke Røre, som den nye Skoleordning vakte i Nordslesvig, at have gjort Myndighederne betænkelige. Bevægelsen afdæmpes synligt i Aarene 1891-92, men kun for derefter paany at tage stærkere Fart i de senere Aar.

Fra 1865-88 indføres der kun tysk Gudstjeneste i 8, fra 1888-97 derimod i 36 nordslesvigske Sogne. Indtil 1888 foregaar Indforelsen planiøst. Naar Kliplev faar tysk Gudstjeneste saa tidlig som i 1878, uagtet der 
ikke bor en eneste tysktalende Familie i Sognet, beror det paa en ren Tilfældighed; efter 20 Aars Forlgb er man endnu ikke naaet videre her, end at denne ciudstjeneste afholdes 5 Gange aarlig og samler hojsst 10 Deltagere. Hvor der som f. E. i Hammelev fincles en hidsig tysk Præst, (født Hannoveraner) tillader man lam at gijøre et Forsøg, uden at man i Forvejen har studeret Forudsatningerne. Reaktionen indtræder da hurtigt af sig selv. Og naar Nederlaget i $\emptyset$ sby bliver mindre ubehageligt, fordi den tyske Gudstjeneste ikke blev atholdt i Kirken men $i$ et privat Hus, skyldtes det aabenbart kun Sognepræsten, den gamle Slesvig-Holstener l'rovst Andresens Forsigtighed og Kjendskab til Forlinldene. Men efter 1888 kommer der Plan og System i Arbejdet, og særlig i de senere Aar, efter at tyske Foreninger her og der, hvor det kniber mest, har fanet et lille Vink om at organisere det tyske Kirkebesøg, el Tilhageslagene faa.

Den tyske Gudstjeneste i nordslesvigske Sogne udvides stærkt efter 1888, uden at Kirkebesøget kan siges at nødvendiggjøre det. I H.jortkjær samlede den tyske Prædiken kun 3-7 Tilhørere, men desuagtet blev der anordnet 5 i Stedet for 2 Gange tysk (judstjeneste aarlig. I Toftlund og Skjærbæk Sogne, hvor den tyske Gudstjeneste gjentagne Gange - i Toftlund endog 4 Gange et enkelt Aar - er falden bort af Mangel paa Deltagelse, er den desuagtet bleven betydelig udvidet. Nange Steder henlægges den tyske Gudstjeneste til om Formiddagen, naar Eftermiddagsgudstjenesten ikke kan opretholdes. Man kan da altid regne med enkelte tilfaldige Deltagere, som af gammel Vane indfinder sig i Kirken disse Dage, uden at luske paa den nye Ordning. 
Et flygtigt Blik paa omstaaende Tavler er nok til at vise, hvad Konsistoriet arbejder hen til som fore$1 ø$ bigt Maal. Det er Indførelsen af tysk Gudstjeneste 15 Gange arlig eller hver fjerde Sonog Helligdag i alle nordslesvigske Kirker.

Man søyer at naa Maalet ved Anvendelsen af en forskjellig Taktik i de enkelte Sogne. Hvor Danskheden endnu er en Magt, snegler man sig langsomt frem fra en ringe Begyndelse for ikke at rakke en for Statskirken farlig Misstemning. Hvor man derimod finder en solid Støtte i noget Hjemmetyskeri, gaar man, skjont Trangen til tysk Kirkesprog slet ikke er storre, frem i store Spring. Hell evad, som viser statskirke-fjendtlige Tendenser, faar kun 2 Gange tysk Gudstjeneste aarlig. Sognene Gam melHaderslev, Uge, Ravsted og Vilstrup faar derimod uden videre 15 Gange tysk Gudstjeneste til at begynde med. Saaledes er det paa mangfoldige Steder let at opdage den politiske Hestefod. I 16 nordslesvigske Sogne afholdes der allerede nu tysk Gudstjeneste hver fjerde Søn- og Helligdag. Konsistoriet vil rimeligvis efter at have naaet dette pavsere lidt $i$ disse Sogne, mens det samler sin Opmærksomhed paa, at faa flere og flere Sogne bugserede frem til dette Standpunkt uden at støde paa farlige Klipper og Skjær. Politisk Klogskab bestemmer Kursen og Farten. Men er man først naaet sail vidt overalt i Nordslesvig, ligger Vanskelighederne hag. Resten kommer da af sig selv. Med et enkelt Pennestrøg kan man saa gjøre hver fjerde til hver anden Helligdag, som Erfaringen fra $\mathrm{H} ø \mathrm{jer}$ viser, og at der ikke er langt fra Sprogenes Ligeberettigelse til Kirkens fuldstændige For skning, det kan man lære af Forholdenes Udvikling ! Sønder-Løgum, Ladelund og flere Sogne. 
Indtil 1888 gaar Indførelsen af tysk Kirkesprog kun undtagelsesvis ud over den danske Gudstjeneste. Ffter 1888 indtræder der ogsaa en Forandring heri. Den danske Gudstjeneste henlægges nu ofte til om Eftermiddagen $o g$ i de senere Aar bortfalder den hyppigt uden egrentlig Nødvendighed. I Oksenvad bortfalder den saaledes 2 Sondage, i Skrave 3 , i Jels 7 og saa videre indtil 15 Søn- og Helligdage aarlig i enkelte Sogne. En bestent Regel kan dog ikke paavises, da stedlige Hensyn og navnlig Sogneprasternes kirkelige og politiske Anskuelser er medbestemmende ved den nye Ordnings Fastsættelse. Derimod er det let at paavise, hvorledes Modersmaalet tilsidesættes mere og mere ogsaa i denne Henseende.

I Reglen anorlnes den tyske Gudstjeneste af Konsistoriet imod Kirkeforstanderskabernes Protest. Enkelte Præster gaar dog ogsaa uden videre frem paa egen Haand, uden at det med tilstrækkelig Fyndighed er bleven paatalt af de paagjældende Kirkeforstanderskaber. Pastor Jakobsen indførte $\mathrm{i}$ sin Tid egenmægtigt tysk Gudstjeneste i Skjærbak; senere er den bleven anordnet af Konsistoriet. Pastor Fischer afholder egenmægtig tysk Gudstjeneste i Højrup Kirke 12 Søndage aarlig o. s. v. Flere Steder afholder Præsterne paa egen Haand tysk Altergang.

Den tyske Gudstjeneste indføres af forskjellige officielle Grunde. Den almindeligste er Hensynet til en eller anden i Sognet ansat Embedsmandsfamilie. Ullerup Sogn i Sundeved fik tysk Gudstjeneste af Hensyn til - 2 tyskfodte Lærerinder, sum ikke forstod Dansk, men desuagtet var blevne ansatte $i$ Sognet for at undervise Smaaborn, som ikke forstod et eneste tysk Ord. Saa vidt drives det 
i Unatur under det preussiske Regimente. Hyppigt foregives der ogsaa Hensyn til gstpreussiske Tjenestefolk. Dette er navnlig Tilfældet i Sogne som Felsted, Ulkebøl og andre, hvor der findes Herregaarde. I nyere 'Tid har den tyske Forening lagt sig efter at fremkalde Petitioner om tysk Gudstjeneste, hvor Hjemmetyskeriet har nogen Udbredelse. Dens Virksomhed spores særlig fra Hellevad over Bedsted ind i Slogs Herred, men kan ogsaa paravises andre Steder.

Næsten alle Vegne opgives det tyske Kirkebesøg som daarligt. Jeg skal ikke anføre Tal, da det ligger i Sagens Natur, at mine Hjemmelsmænd i den Henseende gaar mere efter, hvad de har hort, end efter hvad de har set, og jeg derfor ikke tør tage deres Meddelelser for fuldt paalidelige $\mathrm{i}$ dette Stykke. Det er dog, som ait meddelt en Kjendsgjerning, at den tyske Gudstjeneste flere Steder og gjentagne Gange har maattet bortfalde af Mangel paa Deltagelse. Ligeledes er det en Kjendsgjerning, at de Tysksindede enkelte Steder har inddelt sig i $2-3$ Hold, som har forpligtet sig til skiftevis at deltage i den tyske Gudstjeneste, fordi de foler det som et politisk Nederlag, hvis den atter skulde bortfalde af Mangel paa Deltagelse.

IV.

I den preussiske Statskirke hersker Unionens Aand. Kirken er bleven Statens Træl. Landets højeste og høje kirkelige Myndigheder - evangelisk-lutherske ligesaavel som unionistiske -- betragter Statens Interesser som ensbetydende med Kirkens Interesser. Og Statsinteresserne er ikke et faststaaende Begreb. De bestemmes til enhver given Tid af den tilfældige Regering. Statskirkens høje Embeds-- 
mænd - og Præsternes store Flertal gaar desværre kun altfor villigt $\mathrm{i}$ deres Ledebaand - er derved komne til at indtage en Stilling, som let kan blive overordentlig skjæebnesvanger $i$ vor af stærke sociale og nationale Brydninger opfyldte Tid.

Preussens nyeste Kirkehistorie er lærerig i den Henseende. Der er allerede som Følge af denne Udvikling forefaldet mange alvorlige Sammenstod mellem Kirkeraadet, henholdsvis Konsistorierne og alvorlige tyske Kristne, Lagmænd saavel som Præster. Saaledes har f. E. de horje kirkelige Myndigheders ensidige Tagen Parti for Kejserens Ven, den bekjendte tyske Politiker og store Fabrikherre, Baron v. Stumm i hans Strid med de kristeligsociale Praster og deres Venner paa Egnene ved Saar, vakt megen Uvilje i kirkelige Kredse. Og nu sidst har det vakt pinlig Opsigt, at Konsistoriet i Wiesbaden offentlig har dadlet Synoden i Gladbach skarpt, fordi den har givet Regeringspræsident v. Tepper-Laski sin Misbilligelse til Kjende i Anledning af, at han i de senere Aar har vakt Forargelse ved at jage paa Pintserlagene. Konsistoriet udtaler, at da de borgerlige Love ikke forbyder "Provinseus højeste Embedsmand ${ }^{*}$ - disse Ord understregede - at jage om Søndagen, bor Synoden ikke blande sig i den Sag.

Der synes nu dog $i$ den Henseende at være en Strønkæntring i Sigte i Preussen. Fremragende Præster og indflydelsesrige Universitetslærere har hævet deres vagtige Røster imod det overmodige kirkelige Bureaukrati, og de mange publicistiske Indlæg, som blandt andet ogsaa de her næunte Konflikter har affødt, tyder i hvert Fald paa en stærkt voksende Kritik overfor de falske Stats- 
hensyn, der er bleven Rettesnoren for altfor mange kirkelige Myndigheder i Luthers Fædreland under den protestantiske Kirkes Forfald.

I Nordslesvig mærkes en lignende Strømkæntringr desværre endnu ilike. Vi har længe med Lygte i Haand søgt efter Praster i Statskirken, der har andelig Myndighed til offentlig at optræde imod Konsistoriets Germaniseringsbestræbelser, som - sete fra et kirkeligt Standpunkt - paa Here Omraader frentræder i det grelleste Lys. Men vor sogen har hidtil været forgjæves. Da „de 77 Præster" for nogle Aar siden rejste sig imod Anvisningen af 18. Debr. 1888, blev det, som en Præst meget rigtigt udtalte paa den sidste Provstisynode i Gram, af Befolkningen opfattet som et Lyspunkt. Men Lysjunktet var desværre kun et flygtigt Kornmod, som bayefter gjorde Mørket desto tættere. I'ræsterne stødte paa uventet Modstand, og den bureaukratiske Skole, som de har gjennemgaaet, giver hverken Mod eller líraft til at bære en god Sag frem gjennem tabte Slag. Næppe harde Kultusministeren og honsistoriet givet et lille link, for de fleste Præster opgav Sagen som tabt, og den stolte Skare, som kun Mængden havde givet Mor, var hurtigt splittet ad til alle Sider. Dens store Flertal ved $\mathrm{i}$ sin Raadløshed ikke bedre end at følge det Exenpel, som Bureaukraten Pilatus har givet alle Statstjenere til Efterfolgelse, naar Embedsstillingernes Pligter ængster deres Samvittighed. Føreren, Provst Reuter i Broager, har derimod fuldstændig giort sig til Talerør for Konsistoriet og Regeringen ved angaaende Præsternes Stilling til Skolespørgsmaalet at erklære: „Regeringens Svar foreligger, og der er derefter kun to Udreje for en Embedsmand. Enten siger han: 
Jeg kan og vil nu ikke gaa med Regeringen, og s a a nedlagger han sit Embede, eller han bliver i Embedet og adlyder Regreringen. Det sidste har vi Praster i sonderborg l'rowti giont; derfor tager jeg ikke i Betankning at sige, at vi ikke kan gojore noget videre." Her ser vi den moderne preussiske I'rest som fuldblok Bureatukat, saldeless som Kirkeregimentet snsker det, som en Mand, for hrem statens Interesser galar foran Kirkens Tarv, nalar ham foler siug stillet overfor et uundganelignt Valor. Det er denne burealuratiske Aamd, der mere or mere bliver fremherskende $\mathrm{j}$ den nordslesvirske Gejstlighterl. Or verl siden af brerler Forsagthedens,

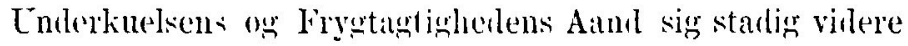
i de hredse, der anduth betragter sign selv som uberonte deraf. Vor Gejistlighed sarmer lland, iet er, natur alt kommer til all, i ()jellikket dens stmete Clykke.

\section{V.}

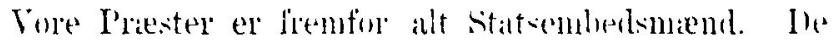

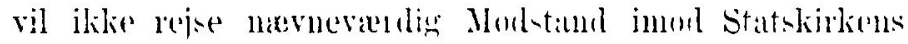

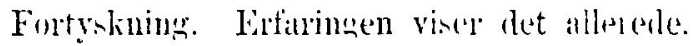

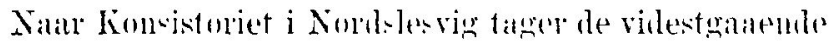

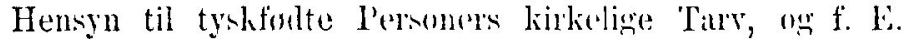
indfonrer tysk ciulstjenteste og ind klaranker den danske Gudstjeneste ai Ilensyn til et l'alr tilfordint ansitte

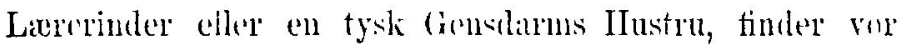
Gejstligherl - sala vidt Offentligheden kjendre dens Lnskuelser det duldstamlin i sin Orden. Der er iklse meget at sige dertil. Ine kan opfatte Prastegjerningen saaledes, at der mita gives alle Sognets Beboere Lejligherl til at hore Ordets Forliyndolse par deres Modersmanl. 
Men hvis de betragter dette som Princip, saa bor de ogsaa være konsekvente og stille det selvsamme Krav, hvor Danskheden udgjor Mindretallet. Mens vor Gejstlighed imidlertid tier og derved godkjender Konsistoriets Germaniseringsbestræbelser i Nordslesvig, har der enduu ikke i Præsternes Rækker løftet sig en eneste Røst imod den danske Gulstjenestes Afskaffelse i saa godt som rent dansktalende Sogne i Mellemslesvig.

Jeg skal her kun opholde mig flygtigt ved de 41 Sogne, hror dell danske Gudstjeneste ophorte allerede i 1864. Et af disse Sogne var Avnt of ved Tønder. Om Sprogforholdene i dette Sogn skriver den tyske Forfatter, Amitretsraad Adler endnu i 1891*: „Det tyske Sprog kan ikke opvise Fremskridt siden 1864. Der tales Dansk i alle Sognets Familier. Kun Præsten o⿺ to Lærere taler Tysk i deres Hjem. “ I dette Sogn, som under den saa stærkt smadede Sprogordningr før 1864, henregnedes til de blandede Distrikter og havde tysk Gudstjeneste hver anden Søn- og Helligdan, blev den danske Gudstjeneste fuldstændig afskaffet under Krigen, fordi Flertallet stemte derfor paa et Tidsjunkt, da Landet var belagt med tysk Indkvartering, og mange var bange for at give deres virkeligge Meningr Ciltryk. Men ingen tysk Præst har nogensinde nerlagt Indsigelse herimod eller paatalt den nuvarende Ordning som uheldig, for at bruge det mildeste Udtryk. Paa samme Maade fik Hanved Sogn ved Flensborg ren tysk Gulstjeneste under Krigen. Sognet

*) Die Tolksqurarle in dtom Herzongthum Schleswig seit 1864 von J. (x. (.) Adler, Amtsurerichtsrath, Flensburg. Zeitselırift der Gesellschaft für Schlesw.-Holstein-Lauenburarisch' Gesehichte ?1 B. 1891 . 
er endnu langt overvejende dansktalende. I 1867 afyav det $75 \%$ danske Stemmer vel Rigsdagsvalget. Gjentagne Gange har langt over Hundrede af Sognets Familier petitioneret om dansk Gudstjeneste men stadig forgjæres. Alt hvad man har opmaaet er Ret til at faa kirkelige Handlinger udførte paa Dansk. Skjønt Sognepræstens Dansk var et sørgeligt Miskmask og mange dankke Sognefolk for ikke at forstyrres i deres Andagt derfor foretrak det tyske Sprog, udførtes $5 \%$ af Daabshandlingerne dog endnu, efter hvad Adler oplyser, paa Dansk i 1891. Hror bliver Konsistoriets omhyggelige Hensyntagen til enkelte Personers kirkelige Trang i disse Sogne, hvor det endda ikke er et fremmed rodlgst Maal, men det nedarvede Folkesprog, som det drejer sig om at gjøre Indronmelser:

I Mellemslesvig beholdt Sognene Bov, Udbjerg, Braderup, Humptrup, Sønderløgum, Karlum, Medelby og Ladelund delvis dansk Kirkesprog efter Krigen. Uagtet disse Sogne imellem Krigene henregnedes til de saakaldte „blandede Distrikter“, var de i Virkeligheden dogr saa godt som rent dansktalende. Jer skial atter her for at undgaa ethvert Skin af at være hildet, holde mig til en tysk Kilde. I den for næevnte Afhandling slildrer Amtsretsraad Adler Sprogforholdene paa dette Strogg i 1891 saaledes: „I de nord for Flensboror, LxkKlægrsbøl liggende Sogne er det danske Folkesprog fremherskende." Denne Paastand støttes derefter paa følgende Enkieltherler:

I Bov Sugn taler 137 Familier tysk, 291 Familier dansk. Der tilfojes i en Note, at Forfatteren ved Familiesiproget forstaar det Sprog, som Forældrene taler med deres Burn, men at dette ofte er forskjelligt fra det Surng, 
der ellers tales i Hjemmet mellem Forældrene indbyrdes og overfor Tyendet. For at forstata Sprogforholdene i dette Sogn maa man nu forst learge Mwrke til, at 48 af Sognets tysktalende Familier findes i den lille Fabrikkoloni Kobbermollen og 21 ved Barlestedet Kollund. Naar man derefter har fradraret et anseligt Antal Embedsfamilier støder man endnu paa det Forhold, at enkelte tysksindede, men elles's dansktalende Familier taler Tysk med bsrnene af Hensyn til skolen. Og dor kommer Adler til det Resultat, at over $86 \%$ af alle Familier i sognets 5 vestligste Landshyor har dansk Familiesprog.

I Ud l,jerer, skriver Aller, har det tyske Sprow ikke rjort kjendelige Fremskridt sirlen 18ti4. Damsk er det almindelige Omgangssproge. Der tales Dansk mect Burnene i 77 og kun Tysk med Bornene i 7 Familier i Singnet.

I braderup ojor drot tyske sprog meget langsomme Fremskridt. Omgangsporoget ar eminn nasten udelukliende damsk. I intet Hus i Sognot tales der udelukhonde Tysk, i 5-6 Ijjen tales der batale Lansk of Tysk mued iblinene.

I H umptrup kan der naple vaere Tale non Frenlskrialt for det tyske sinogin silen 1864. I alle Huve i Sugnet tales dew Lansk. Liun i ren eneste Familie tales der Tysk mod de skolepligtiges lism.

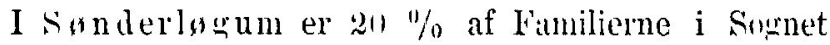
tyslitalende. (Intte Tals Nojugtighed ar sentele hleven

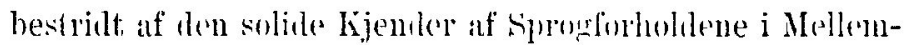
slesvig cantl mag. H. V. Clansen i somd. Aarb. 1892. \$. 190. Irlet jex henviser til Hr. ('lausens Opgionelse, lawler jorr i demu' Forbindelse Tallet stal verl sif Værol.) 
I $\mathrm{K}$ arlum talte i 1891 af 556 Indbyggere 411 Dansk, 80 eller 17 Familier Tysk og 65 eller 16 Familier begge Sprog, det hedder, tilføjer Hr. Adlers Hjemmelmænd, „Tysk med Børnene, iøvrigt Dansk.“

I Medelby talte 186 Familier Dansk, 24 begge Sprog og 23 Plattysk og Højtysk. Det tyske Sprog har gjort væsentlige Fremskridt siden 1864, især er Forstaaelsen af det tyske Sprog taget til efter Krigen.

I Ladelund har det tyske Folkesprog ingen Fremskrilt gjort siden 1864 . Der tales heller ikke Tysk men kun Dansk med de skolepligtige Børn i Sognets dansktalende Familier. Sognet tæller 176 Familier, i 159 er det danske, i 8 det tyske, i 9 begge Sprog Folkesprog.

Saaledes fremstilles Sprogforholdene i disse Sogne fra tysk Side. Vi har foran meddelt, at Bov beholdt dansk Gudstjeneste hver anden Søn- og Helligdag, de øvrige Sogne én Søndag Formiddag og én Søndag Eftermiddag i hver Maaned efter Krigen. Hvorledes er Stillingen nu ?

Kun i Bov Sogn er den uforanuret, i Braderup afholdes der dansk Gudstjeneste 12, i Medelby 4 Gange aarlig. I Sønderløgum, Humptrup, Karlum, Udbjerg og Ladelund afholdes der ikke længere dansk Gudstjeneste.

Er den maaske bleven afskaffet af Mangel paa Deltagelse eller efter Sogneboernes eget Ønske? - vi har jo før set mærkelige Exempler paa sproglig Forvildelse i Mellemslesvig. Hvad det første Spørgsmaal angaar, da meddeler Adler endnu i 1891: I Braderup er den danske Gudstjeneste betydeligt daarligere, næppe halvt saa godt besøgt som den tyske; - - de Personer, der 
forstalar Skriftdansk, ( er de mest kirkeligsindede i Sognet. I Udbjerg forstaas den danske Gudstjeneste, som afholdes 15 Gange aarlig, paa Grund af det danske Skriftsprog uden Tvivl kun til Dels. I det hele bliver den, sandsynligvis af lenne Grund daarligrere besøgt end den tyske. I Ladelund er den danske Gudstjeneste næppe saa godt besqut som den tyske. I Medelby besøges den tyske Gudstjeneste gjennemsnitlig bedre end den danske. Dor indfinder der sig ogsaa et ikke ubetydeligt Antal Kirkegængere til dansk Gudstjeneste. Dette er de tyske Præsters egne Fremstillinger af Forholdene i de Sogne, der endnu havde delvis dansk Kirkesprog i 1891. Man laser tydeligt imellem Linjerne, at den danske Gudstjeneste ikke er ophørt af Mangel par Deltagelse.

Men den er heller ikke, skjønt man gjærne vil give det Udseende deraf, ophørt, fordi Sognebeboerne ønskede det. Allerede da den danske Gudstjeneste 1883 blev afskaffet i Sønderløgum, vakte det en overordentlig stærk Uvilje i Sognet. Men det var særlig gamle Folk ogr Smaafolk, der repræsenterede Uviljen. De fandt ingen Støtte, hverken hos Præst eller Bisp, og stod hjælpeløse uden Førere, uden Forbindelser og uden Fvne til at optagre en alvorlig Kamp for deres kirkelige Interesser. $O g$ da man blev opmærksom paa Forholdet i videre Kredse, var det for sent at hjælpe. Saadan er det vel ogsaa gaaet $i$ Humptrup og Karlum, hvor jeg ikke kjender Forholdenes Udvikling nøje.

Derimod er den danske Gudstjenestes Afskaffelse i L a d elund Offentligheden vel bekjendt, og den illustrerer godt Konsistoriets Germaniseringsbestræbelser. Indtil 1896 
blev der eninu afholdt dansk Gudstjeneste i La delund hver fjerde Søndag. Saa blev Sognepresten imidlertid forflyttet. Embedsinitagterne er smaa, og da der er gode Embeder nok at far i Nordslesvig for Prester, som kan Dansk, var der til at begynde med ingen Ansogere Dette benyttede en lille tysk Klike i Sognet sig af. Under Paaskud af, at der vilde melde sig Here Ansugere, naar den danske Gudstjeneste ophurte, i Værk satte de en Petition desangaaende. Petitionen kom til Forhandling i Sognets tysksindede Kirkekollegium sidst i Marts 1896. Men hvad skete: Fordringen var saa urimelig, at det tyske Kirkekollegium vedtog med 8 imod 5 Stemmer, at der ogsaa i Fremtiden skulde afholdes dansk Gudstjeneste én Søndag hver Maaned. Bagefter løftede der sig betegnende nok $\mathbf{j}$ tyske Aviser et Ramaskrig over, at endog "Folk, som tilhorte tyske Krigerforeninger og ved festlige Lejliyheder havde givet deres tyske Patriotisme Udtryk, ved denne Lejlighed havde stemt for dansk Gudstjeneste."

Som man vel kan tænke sig, vandt denne Afgiørelse lige saa lidt den for næunte tyske Klikes som Konsistoriets Bifald. Der blev straks indgivet en ny Petition, øvet et passende Tryk fra oven, foretaget en ny Afstemning i Kirkeforstanderskabet og nu blev Udfaldet saaledes: 4 Medlemmer af Kirkekollegiet gav ikke Møde, 4 Medlemmer fjernede sig før Afstemningen og derefter blev det med 7 Stemmer vedtaget at anbefale Petitionen. Denne Ordning var Konsistoriet tilfreds med. Det afskaffede nu straks den danske Gudstjeneste i Ladelund Sogn oy udskrev paany Embedet som vakant. I Kundgjørelsen tilføjedes: noget Kjendskab til det danske Omgangssprog er om end ikke nødvendigt saa dog ønskeligt. 
Det er alt, hvad det høje Konsistorium gjør af Indrømmelsex til det danske Sprog, hvor det er det nedarvede Folkesprog, ifolge tyske Kilder endnu tales af $95 \%$, mens det tyske Sprog kun tales af $5 \%$, og hvor mange ældre Folk slet ikke forstaar Tysk! Men ikke én eneste Præst i Nordslesvig har vovet at hæve sin Røst imod Konsistoriet. Vore fromme Præster foretrækker at arbejde for Kristendonmens Udbredelse blandt Hinduer og Zulukaffer. Det kan de gjøre uden at tildrage sig de høje kirkelige Myndigheders Uvilje.

Ladelund Sogn - det er Fremtidsperspektivet for Statskirken i Nordslesvig. Mod det Maal, som i Fjor naaedes der, stiler Konsistoriet, ledet af Slesvigs, i Kiel bosatte, Generalsuperintendent $\mathrm{Hr}$. Kaftan. "Statens Interesser" kræver, at det naas. Derfor arbejder Kirkens høje Embedsmænd for dets Fremme. Kirken lider under dette Arbejde, men det synes ikke at anfægte Præsterne. De er fremfor alt Statens Embedsmænd. De vadsker deres Hænder og gjør iøvrigt "deres Del af Arbejdet for det tyske Sprogs Fremme," som det saa smukt hed i de 77 Præsters Petition. Kun den nordslesvigske Befolkning kan hindre Konsistoriet $i$ at naa Maalet. Vil den gjøre det? Det maa være Fremtiden forbeholdt at afgive Svaret. 